О.В. Самойленко ${ }^{1}$, С.О. Богославець ${ }^{1}$, П.М. Стешенко ${ }^{1}$, Б.Ю. Наусенко ${ }^{1}$

${ }^{1}$ Державний науково-дослідний інститут авіаиії, Київ

\title{
ОСОБЛИВОСТІ КЕРУВАННЯ СПІЛЬНИМИ БОЙОВИМИ ПОРЯДКАМИ БЕЗПІЛОТНИХ І ПІЛОТОВАНИХ ЛІТАЛЬНИХ АПАРАТІВ
}

Надано результати аналізу групового застосування безпілотних літальних апаратів, у тому числі в спільних бойових порядках з пілотованими. Окреслено особливості такого застосування та напрями досліджень, необхідних для розвитку систем автоматичного керування групами літальних апаратів, тендениій створення і застосування високошвидкісних безпілотних літальних апаратів літакового типу.

Ключові слова: безпілотний літальний апарат, групове застосування, автоматичне керування груповим польотом.

\section{Вступ}

Постановка проблеми. Розвиток безпілотної воєнної авіації $€$ одним 3 пріоритетних напрямів озброєння та військової техніки для усіх провідних країн світу. Однак досвід останніх локальних конфліктів, зокрема - бойової експлуатації безпілотних авіаційних комплексів (БпАК) показав обмежені можливості щодо одночасного керування групами безпілотних літальних апаратів (БпЛА).

Разом $з$ тим, застосування групового польоту БПЛА, а також - спільних бойових порядків 3 пілотованими літальними апаратами (ЛА), може підвищити ефективність виконання бойових завдань при менших витратах (часових, матеріальних тощо).

Зазначені дослідження потребують узгодження термінології та визначення понять щодо груп літальних апаратів та їхніх бойових порядків для забезпечення взаємозв'язку і взаєморозуміння між дослідниками, а також споживачами відповідної науково-технічної продукції: публікацій, звітів про науково-дослідні роботи, тактико-технічних завдань та інших супутніх науково-технічних документів.

Аналіз останніх досліджень і публікацій. Авторами враховано розроблений у Державному науково-дослідному інституті авіації національний стандарт ДСТУ В 7371:2020 “Техніка авіаційна державної авіації. Апарати літальні безпілотні. Основні терміни та визначення понять. Класифікація" [1, с. 2..5], а також - термінологія, що наведена в інших нормативних документах, наприклад: група БпЛА, обладнаних системою управління, що дає їм змогу діяти як одне ціле за єдиним завданням i забезпечує уникнення від зіткнень між БпЛА та іншими перешкодами [2, розділ I пункт 2]; груповий політ - політ, в якому беруть участь кілька повітряних суден, які виступають як єдине повітряне судно стосовно навігації і повідомлень про місцезнаходження, а також отримання дозволів від органів управління повітряним рухом [3, розділ 7 пункт 3]; бойовий порядок - розташування (шикування) підрозділу, частини, з'єднання з їхніми засобами підсилення для ведення бою [4, с. 530].

Попередній аналіз ефективності можливого групового застосування сучасних БПЛА показує такі основні його переваги [5, с. 29]:

складність оцінки кількісного складу БпЛА и супроводження інформаційно-керуючими системами противника, особливо при прояві ефекту “рій”, коли кількість БпЛА перевищує пропускну здатність засобів протидіі;

можливість організації спільної обробки інформації в групі, що забезпечує підвищення інформативності та живучості;

розширення простору інформаційно-керуючого покриття, що може забезпечити значення коефіцієнта ефективності бойового застосування БпЛА спільно 3 пілотованими ЛА, який дорівнюватиме 0,7 [6, с. 32].

Ці висновки підтверджуються реальним досвідом масованого бойового застосування БпЛА в останні десятиліття, наприклад, для викриття протиповітряної оборони (ППО) противника ізраїльськими БпЛА в Лівані у 1982 році або азербайджанськими літаками Ан-2 без пілотів на борту (після самостійного ними покидання літака) в Нагорному Карабасі у 2020 році. Також відомі випадки застосування груп ударних БпЛА: бойовики "Ісламської держави" нанесли декілька ударів по російським військам в Сирії у 2018 році, йєменські хусити у 2019 році підірвали над парадом урядових військ Йємена групу БпЛА начинених вибухівкою та елементами ураження, а також - атакували нафтобазу Саудівської Аравії. 
3 огляду на зазначене у провідних країнах світу здійснюються дослідження щодо спільного застосування груп БПЛА та пілотованих літальних апаратів. Так, наприклад, в США [7, с. 7 . .8; 8, с. 53...55]:

в армійській авіації відпрацьовується порядок дій спеціалізованого ударного гелікоптера АН-64Е ApacheGuardian спільно з БпЛА RQ-7B Shadow-200 та MQ-1C GreyEagle;

у військово-морських силах проведено роботи у рамках спряження БпЛА MQ-4C Triton та пілотованих літаків дальнього радіолокаційного виявлення та управління E-2D, літаків радіоелектронної боротьби ЕА-18G Growler;

у повітряних силах розроблено систему управління ударним БпЛА з борта літака типу F35А, а також - розвідувально-ударну систему на основі транспортного (пілотованого або безпілотного) літака C-130 Hercules та розвідувальних і ударних БпЛА типу Gremlins.

Мета статті - дослідження можливостей організації групового польоту БпЛА, а також спільного групового польоту БпЛА і пілотованих ЛА, заснованих, наприклад, на принципі “ведучий ЛА - ведений БпЛА”.

\section{Виклад основного матеріалу}

Під час виконання теоретичних досліджень дослідно-конструкторських робіт у зазначеній сфері потрібно враховувати енергетичні особливості процесів керування бойовими порядками ЛА і БпЛА та відповідні обмеження.

Група БПЛА або ЛА має більш низькі льотні характеристики порівняно з одиночним літаком. Для стабілізації та керування зміненням параметрів бойового порядку відомий БПЛА (ЛА) потрібно майже постійно коригувати (зміною тяги силової установки та положення кермових поверхонь) параметри польоту (швидкість, кутове положення, висоту). Тому у нього повинен бути резерв тяги силової установки та швидкості, величина яких залежить від параметрів бойового порядку, способу пілотування, маневрів, що виконуються, кількості БпЛА (ЛА) в групі, метеорологічних умов, а також (у випадку ЛА) - натренованості льотчиків [9, с. 353].

Так, якщо група літаків здійснює політ у зімкненому бойовому порядку, то виконання розворотів такої групи має низку особливостей порівняно 3 розворотом одиночного літака. Так, наприклад, збереження заданих параметрів бойового порядку досягається за умови постійності кутової швидкості розвороту. На рис. 1 показано схему бойового розвороту ланки БпЛА.

3 розгляду схеми, наведеної на рис. 1, видно виконання умови постійності кутової швидкості розвороту [9, с. 354$]$ :

$$
w_{c}=\frac{V_{1}}{R_{1}}=\frac{V_{2}}{R_{2}}=\cdots=\frac{V_{n}}{R_{n}} .
$$

Тоді, величини швидкостей польоту ведених БпЛА можна визначити із рівності

$$
V_{n}=V_{1}\left(1+\frac{\sum_{i=1}^{n-1} z_{i}}{R_{1}}\right) \text {. }
$$

Отже, для ведених БпЛА вимагається більше відхилення органу керування силовою установкою, а також - інших органів керування, i, як наслідок, посилюються вимоги до пристроїв приводу системи автоматичного керування.

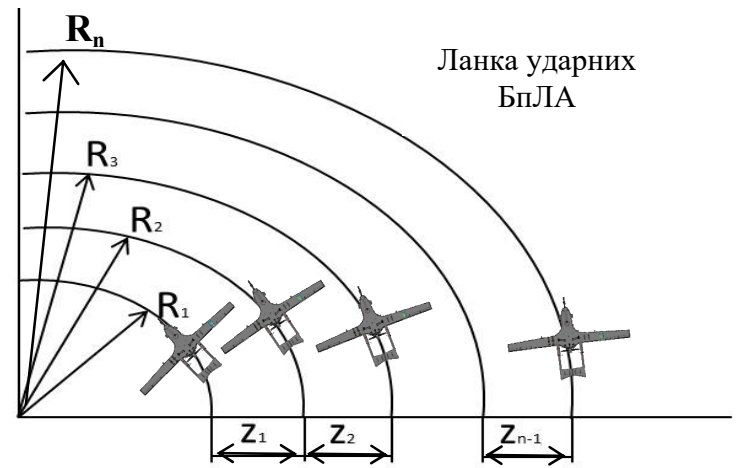

Рис. 1. Схема бойового розвороту групи БпЛА

Джерело: розроблено авторами за даними [9, с. 354].

3 огляду на зазначене, для підтримання параметрів обраного бойового порядку важливим $€$ вибір додаткових джерел інформації для систем автоматичного керування груповим польотом БпЛА. Тому що сучасні бортові навігаційні системи не мають достатню точність i не можуть бути використані для забезпечення групових польотів у зімкнутих бойових порядках. Тому проводяться дослідження із застосування різних фізичних принципів для створення вимірювачів положення БПЛА в бойовому порядку. У якості вимірювачів параметрів строю БпЛА пропонують акустичні, ультразвукові, лазерні, радіоактивні, радіотехнічні й інші системи. Розглянемо особливості деяких з них.

Перевагою акустичних і ультразвукових систем відзначається можливість забезпечення поширення сигналів у межах тільки максимально можливої дальності між БпЛА, що забезпечує високу завадостійкість і прихованість. Однак, властиві їм недоліки - мала швидкодія, порівняно великі габарити апаратури та вплив неоднорідності атмосфери на поширення звукових хвиль - не дозволяють створювати на їхній основі достатньо ефективні системи керування.

Лазерні вимірювальні системи здатні забезпечити необхідну точність визначення положення БпЛА в групі. Крім того, до складу бортового обладнання 
багатьох типів БпЛА для виявлення і розпізнавання цілей, вирішення прицільних задач, входить оптикотелевізійна система, яку можна використовувати додатково і як вимірювач параметрів строю. Але промінь оптичного когерентного генератора вузький, тому організація збирання БПЛА в групи ускладнюється. До того ж туман, дощ і дим сильно послаблюють промінь лазера.

Сучасні радіотехнічні системи для вимірювання взаємного положення транспортних літаків і вертольотів в повітрі використовують принцип “запит-відповідь” i “частота-час". Так, наприклад, радіотехнічні датчики, що використовуються в системі типу AN/APN-169, здійснюють вимірювання дальності з точністю $\pm 5 \%$ від вимірюваної відстані, а направлення - 3 похибкою $\pm 2 \%$ від величини азимуту. Суттєвим недоліком цих систем $є$ те, що вони дозволяють визначити параметри строю тільки в розосереджених бойових порядках, в яких значення інтервалів та дистанцій знаходяться у діапазоні від 2 км до 30 км. Крім того, у випадку використання такого принципу вимірювання на всіх ЛА необхідне встановлення на борту високоточних годинників, синхронізованих між собою. Це призводить до ускладнення бортової апаратури й обмеження застосування таких систем на одноразових ударних БПЛА, для яких найважливішою вимогою є мінімум вартості бортового обладнання.

Доцільно оцінити придатність для керування групою БпЛА в умовах зімкнутого строю радіонавігаційної системи, яка вимірює координати ЛА на основі трилатераційного методу. Перевагами такої системи є порівняно невисока вартість та вага бортового обладнання БПЛА, можливість виконувати групові польоти в зімкнутих бойових порядках 3 мінімальним складом бортового обладнання, висока точність доставлення авіаційних засобів ураження й достатня гнучкість при вирішенні завдань оперативного управління групою. Ця система дозволяє 3 високим рівнем точності виконати обчислення координат повітряного об'єкта за певним значенням базису та виміряними дальностями до БпЛА.

На відміну від відомих радіодалекомірних способів навігації БпЛА особливістю трилатераційного методу вимірювання координат $€$ те, що визначення місця розташування повітряного об'єкта здійснюється не на самому повітряному об'єкті, а на одній 3 наземних станцій, і тому вимірювання дальності здійснюється зі значно більшою точністю, що характеризується середньоквадратичною похибкою до 4 м [10, с. 6]. Послідовність вимірювання координат БпЛА зазначеним методом включає нижченаведене. На землі розташовуються станція контролю і керування
(СКК) та ще одна станція з відомими координатами (відома станція), пов'язані між собою за допомогою інформаційного каналу (рис. 2).

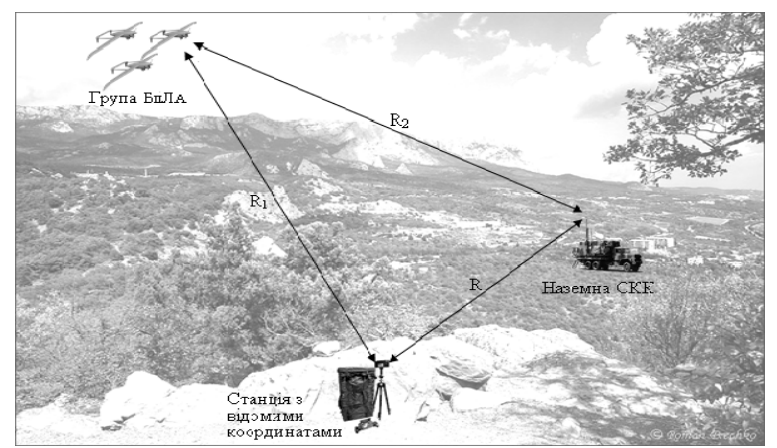

Рис. 2. Вимірювання координат трилатераційним методом.

Джерело: розроблено авторами за даними [10, с. 6]. Ці станції розташовані у певних топоприв'язаних точках і відстань між ними $R$ точно визначена. Для вимірювання дальності до БПЛА 3 СКК випромінюється широкосмуговий сигнал $з$ модуляцією за фазою псевдовипадковою послідовністю. Цей сигнал випромінюється в напрямку можливого знаходження усіх БпЛА, що здійснюють груповий політ. Крім того, частина сигналу випромінюється в напрямку відомої станції. Приймач - передавач БпЛА перевипромінює прийнятий сигнал, який приймається як на СКК, так і на відомій станції, причому передавач кожного БПЛА перевипромінює прийнятий сигнал із зсувом за частотою. Прийнятий на СКК сигнал коригується копією випроміненого сигналу (опорним сигналом), який знаходиться у приймачі, 3 метою визначення відносної фази між ними. Фазовий зсув між прийнятим i опорним сигналами пропорційний подвоєній відстані до БпЛА. Сигнал, прийнятий від БПЛА на відому станцію, порівнюється з сигналом, який приймається від наземної СКК, й таким чином визначається дальність $R_{1}+R_{2}$ (рис. 2). Дальності до кожного БпЛА групи, які вимірюються на відомій станції, передаються на СКК й заводяться в цифрову обчислювальну машину. Туди ж надходить $i$ дальність $R_{1}$, що виміряна на СКК. Виміряні значення $R_{1}$ і $R_{1}+R_{2}$ та відомий базис $R$ однозначно визначають координати кожного БпЛА групи.

Крім того, частина сигналу випромінюється в напрямку відомої станції. Приймач - передавач БпЛА перевипромінює ведучий сигнал, що приймається як на СКК, так і на відомій станції, при цьому, передавач кожного БпЛА перевипромінює прийнятий сигнал із зсувом за частотою. Прийнятий на СКК сигнал корелюється 3 наявною в приймачі копією випроміненого сигналу (опорним сигналом) для точного визначення відносної фази між ними. Фазове зрушення між прийнятим і опорним сигналом буде пропорційним подвоєній відстані до БпЛА. 
На веденій станції прийнятий від БпЛА сигнал порівнюється із сигналом, прийнятим від СКК й, таким чином, визначається дальність $R_{1}+R_{2}$. Вимірювані на відомій станції дальності до кожного строю БПЛА передаються на СКК і заводяться в наземну цифрову обчислювальну машину. Туди ж надходить і дальність $R_{l}$, вимірювана на СКК. Відомий базис $R$ і виміряні значення $R_{1}$ та $R_{1}+R_{2}$ однозначно визначають координати кожного БПЛА, що, у свою чергу, дозволяє обчислити поточні параметри строю. Для збільшення дальності дії системи, крім названих пунктів, необхідно застосовувати додаткові повітряні пункти (наприклад, БПЛА), що працюють як ретранслятори.

Точність визначення місця розташування БпЛА відносно СКК становить на відстані 50 км $15 \pm 2,0$ м, на відстані 80 км - 25 $\pm 3,0$ м [10, с. 7]. Висока точність визначення координат літальних апаратів i, тим самим параметрів строю, дозволяе робити групові польоти БпЛА в зімкнутих бойових порядках.

Вивчення можливих способів i варіантів побудови систем автоматичного керування груповим польотом БпЛА дозволяе зробити висновок, що впровадження системи, яку засновано на трилатераційному методі вимірювання параметрів, приведе до скорочення вартості i навантаження бортового обладнання БпЛА, дозволить 3 мінімальним складом бортового обладнання виконувати групові польоти в зімкнутих бойових порядках, забезпечуючи при цьому високу точність доставки засобів ураження й високу гнучкість при рішенні завдань оперативного керування групою. Разом з тим, слід зауважити, що недоліком трилатераційних вимірювальних систем $€$ те, що сучасні методи і засоби радіоелектронної протидії супротивника можуть впливати на їхню роботу, що може привести до втрати спостереження і керованості групи БпЛА.

\section{Висновки}

Таким чином, аналіз існуючих підходів при рішенні завдань синтезу систем автоматичного керування показує, що питання вдосконалення алгоритмів керування груповим польотом БпЛА потребує врахування показників точності систем навігації, у т.ч. міжлітакової, а також енергетичних особливостей процесів керування групою літальних апаратів. 3 огляду на зазначене, Державним науково-дослідним інститутом авіації проводяться дослідження щодо синтезу алгоритмів автоматичного (автоматизованого) керування безпілотними і пілотованими літальними апаратами для застосування у спільних бойових порядках на основі побудови математичної моделі польоту групи бойових безпілотних та пілотованих літальних апаратів. Практичним результатом цих досліджень будуть загальні технічні вимоги до перспективних систем керування БпЛА і пілотованих ЛА для їх застосування у групах у спільних бойових порядках.

\section{Список літератури}

1. ДСТУ В 7371:2020 Техніка авіаційна державної авіації. Апарати літальні безпілотні. Основні терміни та визначення понять. Класифікація. - К.: УкрНДНЦ, 2021. - 21 с.

2. Правила виконання польотів безпілотними авіаційними комплексами державної авіації України: затв. нак. МОУ 08.12.2016 № 661. - К.: Міністерство оборони України, 2016. - 79 с.

3. Правила польотів державної авіації в повітряному просторі України. Наказ МО України від 09.12.2015 № 700 .

4. Советская военная энциклопедия. М.: Воениздат, 1976. -Т.1.- 530 с.

5. Моисеев В.С. Групповое применение беспилотных летательных аппаратов: монография. - Казань: Редакционноиздательский центр “Школа”, 2017. - 572 с. (Сер. “Современная прикладная математика и информатика”).

6. Матеріали міжнародного науково-практичного семінару: спільне застосування пілотованих та безпілотних бойових систем / Повітряна міць держави. Том 1, вип. №1 (2021) - К.: НУОУ // [Електронний ресурс]. - Режим доступу: sap.nuou.org.ua.

7. Звіт про складову частину НДР “Взаємодія”. -К.: ДНДІА, 2020. - 87 с.

8. Д.Стрельников, А. Сидоров, Ю. Мгимов. Совместное применение пилотируемой и беспилотной авиации США в первой половине XXI века // Зарубежное военное обозрение. 2018, №4. - С. 52-59.

9. Большие технические системы: проектирование и управление / Л.М. Артюшин, Ю.К. Зиатдинов, И.А. Попов, А.В. Харченко. Под ред. И.А. Попова. - Х.: Факт, 1997. - 400 с.

10. Л.М. Артюшин. Методичний підхід до вирішення завдань відмовостійкого автоматичного керування груповим польотом безпілотних літальних апаратів // Системи озброєння і військова техніка. - Х.: ХНУПС, 2005. - № 1(1). - С. 3-10. 


\section{Відомості про авторів:}

\section{Самойленко Олексій Валерійович}

кандидат технічних наук старший науковий співробітник начальник науково-дослідного відділу

Державного науково-дослідного інституту авіації, Київ, Україна

https://orcid.org/0000-0002-3088-3268

\section{Богославець Сергій Олександрович}

кандидат технічних наук старший науковий співробітник провідний науковий співробітник Державного науково-дослідного інституту авіації, Київ, Україна

https://orcid.org/0000-0001-5899-7833

\section{Стешенко Петро Миколайович}

кандидат технічних наук провідний науковий співробітник

Державного науково-дослідного інституту авіації, Київ, Україна

https://orcid.org/0000-0003-1432-6864

\section{Наусенко Богдан Юрійович}

ад'юнкт

Державного науково-дослідного інституту авіації, Київ, Україна

https://orcid.org/0000-0002-7208-1116

\section{Information about the authors:}

\author{
Oleksiy Samoylenko \\ Candidate of Technical Sciences \\ Senior Researcher \\ Head of Research Department \\ of State Research Institute of Aviation, \\ Kyiv, Ukraine \\ https://orcid.org/0000-0002-3088-3268
}

\author{
SerhiyBohoslavets \\ Candidate of Technical Sciences \\ Senior Researcher \\ Leading researcher \\ of State Research Institute of Aviation, \\ Kyiv, Ukraine \\ https://orcid.org/0000-0001-5899-7833
}

\author{
Petro Steshenko \\ Candidate of Technical Sciences \\ Leading researcher \\ of State Research Institute of Aviation, \\ Kyiv, Ukraine \\ https://orcid.org/0000-0003-1432-6864
}

\section{Bohdan Nausenko}

$\mathrm{PhD}$ student

of State Research Aviation Institute,

Kyiv, Ukraine

https://orcid.org/0000-0002-7208-1116

\title{
SOLUTION FOR TASK MINIMIZATION RISKS OF IMPORT SUBSTITUTION IN THE PROCESS OF MILITARY AEROTECHICS FACTORY REPAIR IN THE CONDITIONS OF THE SPECIAL PERIOD
}

\author{
O. Samoylenko, S. Bohoslavets ,P. Steshenko, B. Nausenko
}

The article presents the analysis results of the question of ensuring the post-repair reliability of military aviation equipment, while adjusting the production of component parts (spare parts, units) by domestic enterprises in the process of import substitution. System of aviation equipment maintenance of state aviation is a complex multifactorial, essentially nonlinear and non-stationary system, so one of the expedient approaches to assessing the influence of risk-forming factors on ensuring a given level of serviceability of a fleet of aviation equipment is to consider analogies for a system of adequate complexity. Such system is considered the system of aircraft repair company when performing import substitution measures with appropriate risks. The most significant risks of the implementation of measures of import substitution in the process of factory repair of aviation equipment of state aviation, which are not subject to copyright supervision, are listed. Each risk is characterized. The algorithm of formation of the plan of repair of aviation equipment, at which the minimal risk of providing the set level of serviceability of thestate aviation park for each of the possible scenarios of a special period is presented. Quantitative evaluation of the measure of the feasibility of a program measure is carried out by calculating the probability of occurrence of determining risks on the basis of the synthesis of scientific and methodological apparatus of risk theory and fuzzy sets theory. The authors propose to improve the existing methodological approach to assessing the expectation of the occurrence of a specific risk of a program measure in terms of its adaptation to the features of a program measure such as the procurement project, clarification and extension of the list of major risk-forming factors affecting the success of the procurement and implementation project Sugeno. Recommendations are given to minimize the risks of import substitution of factory repair processes in the special period. The recommendations relate to the state defense policy, the legal basis for the technical documentation of enterprises, measures on materials science and production technology, taking into account the dependence of the level of reliability on the design and schematic solutions.

Keywords: aviation repair enterprise, import substitution, risk, factory repair, post-repair reliability, resource,level of good condition, special period. 